\title{
Source identification of fine and coarse aerosol during smog episodes in Debrecen, Hungary
}

\author{
Anikó Angyal ${ }^{1}$ (1) $\cdot$ Zita Ferenczi $^{2} \cdot$ Manousos Manousakas $^{3}$ • Enikő Furu ${ }^{1} \cdot$ Zoltán Szoboszlai $^{1,4} \cdot$ Zsófia Török $^{4}$. \\ Enikő Papp ${ }^{4} \cdot$ Zita Szikszai $^{1} \cdot$ Zsófia Kertész $^{1,4}$
}

Received: 13 December 2020 / Accepted: 15 March 2021 / Published online: 12 April 2021

(C) The Author(s) 2021

\begin{abstract}
In this study, the identification of PM sources during smog episodes in Debrecen is presented. The smog episodes were characterized by the high concentration of $\mathrm{PM}_{10}$, and were linked to a thermal inversion period in November 2011 in Hungary, when an anticyclone occurred across Europe. The sources of $\mathrm{PM}_{2.5}$ and $\mathrm{PM}_{\text {coarse }}$ were identified by positive matrix factorization (PMF). Additionally, the source locations were explored by using the conditional probability function (CPF). A numerical weather prediction model (WRF) was also applied to evaluate the air pollution situation. In order to meet the goals of the study, the elemental composition with high (2-h) time resolution, the elemental size distribution, and the planetary boundary layer were examined in an urban background site of downtown Debrecen, Hungary. Our results highlight the importance of biomass burning (39\%) and traffic $(31 \%)$ as the major contributors to $\mathrm{PM}_{2.5}$. The main tracers of these sources $(\mathrm{K}, \mathrm{Cl}, \mathrm{Pb}, \mathrm{Zn})$ appeared mainly in droplet mode $(0.5-1 \mu \mathrm{m})$. The major sources of $\mathrm{PM}_{\text {coarse }}$ fraction were soil $(32 \%)$, and dust attributed to tramline construction (30\%). The combination of PMF and CPF results revealed that the $\mathrm{PM}_{10}$ concentrations were affected by sources within the urban agglomeration of Debrecen (city centre and suburban areas) under the given meteorological conditions. This conclusion is further validated by the fact that the diurnal variation of the identified source contributions presented a distinct pattern that depended strongly on the daily activities of the city's residents (compared to the usually unstructured diurnals of transported sources).
\end{abstract}

Keywords Smog episodes $\cdot$ Elemental composition with high time resolution $\cdot$ Elemental size distribution $\cdot$ Source apportionment $\cdot \mathrm{CPF}$

\section{Introduction}

Over the last decades, human exposure to particulate matter (PM) related pollution has been associated with a broad range of adverse health effects, including cardiovascular and

Anikó Angyal

angyal.aniko@atomki.hu

1 Laboratory for Heritage Science, Institute for Nuclear Research (ATOMKI), Bem tér 18/c, Debrecen H-4026, Hungary

2 Hungarian Meteorological Service, Kitaibel Pál u. 1, Budapest H-1024, Hungary

3 Laboratory of Atmospheric Chemistry, Paul Scherrer Institute (PSI), 5232 Villigen, Switzerland

4 Isotope Climatology and Environmental Research Centre (ICER), Institute for Nuclear Research (ATOMKI), Bem tér 18/c, Debrecen H-4026, Hungary respiratory morbidity and mortality (Pope and Dockery 2006). Subpopulation groups such as children and the elderly are more susceptible to PM-induced health effects because of their physiological differences (Jason et al. 2011). PM-related pollution occurs predominantly in the densely populated urban areas, where more than $70 \%$ of the EU population lives (EEA 2018).

Urban air quality is influenced by a large number of different factors. It depends mainly on the emission rates of air pollutants, which is in turn affected by the location and contributions of the various emission sources. Additional factors, such as meteorological conditions and topography (i.e., mountainous areas and basins) can also contribute by enhancing air pollution phenomena and create pollution events like summer or winter smog formation.

The weather conditions and air quality are interrelated: the dispersion or accumulation of pollutants emitted into the urban air-shed can be strongly influenced by the formation of lowlevel temperature inversions in the planetary boundary layer 
(PBL). These events are very frequent in urban environments (EEA 1998). In Hungary, wind speed and planetary boundary layer are the variables that strongly influence PM levels.

In the EU, there are no common standards or guidelines regarding information and alarm thresholds for temporary extremely high PM-related pollution. The local governments and/or municipalities are responsible for informing the public and enforce all necessary actions/measures (Wiesen 2017). On the other hand, the EU environmental policy expressed by the Air Quality Directive (Council Directive 2008/50/EC) calls attention to the increased importance of effective air quality plans for the mitigation of particulate pollution, and consequently, human exposure risk. The experience gained during the last decades of air quality monitoring and management has made it very clear that further mitigation of PM pollution is needed. If control measures are to be effective, it is imperative to identify the major PM sources and target specifically the reduction of the emissions from these sources, which are the ones that contribute most in a given area or/and during high pollution events such as smog episodes.

Hungary lies in the Carpathian Basin which has been found to be very sensitive to particulate-related pollution according to the findings from previous studies, experiencing severe events in many cases (Ferenczi 2013; Molnár et al. 2016). In Hungary, these events are more frequent under anticyclonic weather conditions in autumn and winter (Cséki 2010). The geographical location of Hungary - a basin surrounded by the Carpathians, the Alps, and the Dinaric Alps - strongly favours stagnant weather conditions. Because of the combined effect of the weather conditions and geographical location, aerosol smog episodes (smog created by high concentrations of PM) occur typically in autumn and winter in Hungarian cities. During these severe air pollution events, PM concentrations are very high, posing additional risks to human health.

In Hungary, the information $\left(75 \mu \mathrm{g} / \mathrm{m}^{3}\right)$ and the alarm threshold value $\left(100 \mu \mathrm{g} / \mathrm{m}^{3}\right)$ for the $\mathrm{PM}_{10}$ concentration were introduced by the government on 25th October, 2008 (MDVM 2011). In large cities, a monitoring network is operated by the Hungarian Air Quality Network (www. levegominoseg.hu), which collects and reports data on $\mathrm{PM}_{10}$ and other gaseous pollutant concentrations $\left(\mathrm{SO}_{2}, \mathrm{CO}, \mathrm{NO}_{\mathrm{x}}\right.$ etc.). However, the agencies are not obliged to identify and report data on individual PM sources and consequently, there is no information about the contribution of each source to the total PM mass concentration.

To meet the need for PM source identification, receptor models, such as Positive Matrix Factorization (PMF), have been proven to be useful and reliable tools (Viana et al. 2008; Belis et al. 2013). PMF has been successfully applied in areas with many different characteristics in regions all around the world. Information about several components of $\mathrm{PM}$ such as the elements, ions, organic and elemental carbon are usually included in such studies (Almeida et al. 2020;
Banerjee et al. 2015; Pateraki et al. 2019). The most commonly identified sources include soil, secondary aerosols, vehicular emissions, fossil fuel burning, biomass burning, sea salt and industrial emissions (Pant and Harrison 2012; Sharma et al. 2016). One of the most important parameters in the receptor modeling analysis is the selection of source signature/source profile. Source signature refers to the mix of tracer elements and/or molecular markers used for identification of sources (Pant and Harrison 2012). The assignment of factors from multivariate receptor models to specific source categories is in many cases highly questionable as factors often include combinations of chemical constituents that are of low plausibility. To assist the factor identification in some studies, the chemical reconstruction or/and the examination of elemental ratios has been used (Sharma et al. 2014a, b).

Source apportionment has usually been conducted by offline filter sampling, and the period of sampling and chemical analysis of PM tends to be relatively long. This is not conducive to the rapid analysis required for a better understanding of the causes of smog events. Additionally, the relatively low time resolution of source apportionment results prevents policymakers from taking effective control measures for fast-changing emission sources. To obtain more accurate results, aerosol particle composition data with high time resolution and mass size distribution are required (Vecchi et al. 2008; Richard et al. 2011). Another factor that provides valuable supplementary information to source apportionment studies to help ensure accurate aerosol source identification is the analysis of meteorological data (planetary boundary layer, wind speed, wind direction etc.).

There are a few studies in Central Europe which focus on areas with high ambient $\mathrm{PM}_{10}$ concentrations in Ostrava (Czech Republic) (Leonia et al. 2018), Krakow (Poland) (Mira-Salama et al. 2008) and K-puszta (Hungary) (Molnár et al. 2016). Most of these studies involve particle mass concentration, composition, optical properties and source apportionment in smog episodes. Two studies have presented results of receptor modeling on high time (1-h and 2-h) and sizeresolved $\left(\mathrm{PM}_{0.15-1.15}, \mathrm{PM}_{1.15-10}\right.$, and $\left.\mathrm{PM}_{0.09-0.26}\right)$ elemental composition data collected during smog and post-smog periods in Ostrava, Czech Republic, a European air pollution hot-spot (Pokorna et al. 2015; Pokorna et al. 2016). They highlighted the importance of the impact of the fugitive and coal combusting low-height aerosol sources during the inversion period and industrial aerosol emissions during post-smog period to the urban air quality of the Ostrava-Radvanice and Bartovice district during the winter period. As for the air quality worsening in residential areas, the proximity of industry must be considered when control-emission tecniques are applied (Hovorka et al. 2015).

In our previous study in Debrecen, Hungary, a series of sampling campaigns were used to identify and characterize the sources of fine and coarse particulate matter. The 
campaigns were carried out throughout a 2-year long period under different meteorological conditions and during different seasons. The samples were collected in 2-h time resolution at an urban background site. The following sources were identified: traffic through direct emission and re-suspended soil dust, mineral dust, biomass burning as domestic heating, source characterized by $\mathrm{Cl}$, secondary sulphate from combustion, regional background and agriculture (Kertész et al. 2010).

High APM levels called smog occur frequently in Debrecen and similar cities in the region during winters, between November an February. Under favourable meteorological conditions, these episodes can last 5-15 days long.

In this study, two successive long-drawn smog episodes caused by an anticyclone in November 2011 were chosen to characterize the APM pollution and provide a unique snapshot of the contributing sources for such periods. At the same time, the size distribution of PM was also examined. Positive Matrix Factorization (EPA PMF 5.0) receptor model was applied to characterize the PM sources in Debrecen, using high time resolution elemental data as input. Additionally, we assessed the effects of meteorological parameters such as the planetary boundary layer, wind direction and speed, using conditional probability function and a numerical weather prediction model.

\section{Receptor site}

The city of Debrecen with approximately 220,000 inhabitants is situated at the eastern part of the country in the Great Hungarian Plain. It has a mixed-fired power plant, a waste incinerator, an airport and it is surrounded by agricultural areas. Based on regional environmental agency reports $(\mathrm{GOHBCH}$ 2020 ), the main primary sources of pollution are trafficrelated (non-exhaust and exhaust emissions). Since the economic crisis of 2008, increased use of biomass burning for residential heating has been recorded during the heating season.

The receptor site was a rooftop sampling station (at a height of about $5 \mathrm{~m}$ above street level) on the Atomki premises $\left(47.5437^{\circ} \mathrm{N}, 21.6252^{\circ} \mathrm{E}\right)$. The site is shielded from the direct impact of pollution sources. The map of Debrecen including the sampling site and the official monitoring sites operated by the Hungarian Air Quality Network (HAQN n.d) are shown in Fig. 1. After examining the correlation of the data from HAQN station to the ones retrieved in our site, data from HAQN1 station situated in Debrecen were used as complementary to the ones obtained by this study, while HAQN2 and HAQN3 are reported for comparison. The HAQN1 monitoring station is situated approximately $900 \mathrm{~m}$ from our sampling site to the north, in the forest park region. In the near/ immediate vicinity of the sampling site, there is a main road to the west, national road no. 33 to the south, and a street with a tramline to the east.

\section{Experimental}

\section{Aerosol sampling}

For the sampling campaigns, a two-stage sequential PIXE (Particle Induced X-ray emission) International streaker (Annegarn et al. 1996) was used to study the quasi-hourly evolution of atmospheric aerosol concentration. The sampling device collected two different size fractions separately with a time resolution of $2 \mathrm{~h}$ in November, 2011. The coarse fraction ( $\mathrm{PM}_{\text {coarse }}$, particles with aerodynamic diameter between 2.5 and $10 \mu \mathrm{m}$ ) was deposited on a kapton foil coated with metal free paraffin, while the fine fraction $\left(\mathrm{PM}_{2.5}\right.$, particles with aerodynamic diameter equal or smaller than $2.5 \mu \mathrm{m}$ ) was collected on Nucleopore polycarbonate filters with $0.3 \mu \mathrm{m}$ pore diameter. The aerosol sampling was carried out with a flow rate of $1 \mathrm{~L}$ $\min ^{-1}$. Furthermore, size-resolved samples were collected by a ten-stage PIXE International cascade impactor (Maenhaut et al. 1996) in the following size fractions: $>16,16-8,8-4,4-2,2-1$, $1-0.5,0.5-0.25,0.25-0.12,0.12-0.06$ and $<0.06 \mu \mathrm{m}$ aerodynamic diameter. In this case, a coated kapton foil was applied as impactor surface. The sampling site described in section "Receptor site" can be considered as an urban background site in downtown Debrecen. The sampling campaigns with a streaker were carried out from 2 to 8 November and from 15 to 21 November, 2011. The sampling using the cascade impactor took place between 2-5, 7-9 and 15-17 November, 2011.

\section{Analysis and data evaluation}

\section{Elemental analysis}

The elemental composition of the aerosol samples (atomic number $13 \geq Z$ ) was determined by particle induced $\mathrm{X}$-ray emission (PIXE) method. The measurements were performed at the PIXE chamber installed on the left $45^{\circ}$ beamline of the 5 MV Van de Graaff accelerator of Atomki (Borbély-Kiss et al. 1985). The irradiation was done by a proton beam of $2 \mathrm{MeV}$ energy. The beam intensity was $50 \mathrm{nA}$ and the accumulated charge was $40 \mu \mathrm{C}$ for each sample. The PIXE spectra were evaluated using the PIXEKLM program package (Szabó and Borbély-Kiss 1993; Szabó 2009), which provided absolute elemental concentration values for the following elements: $\mathrm{Al}, \mathrm{Si}, \mathrm{P}, \mathrm{S}, \mathrm{Cl}, \mathrm{K}, \mathrm{Ca}, \mathrm{Ti}, \mathrm{V}, \mathrm{Mn}, \mathrm{Fe}, \mathrm{Ni}, \mathrm{Cu}, \mathrm{Zn}, \mathrm{Br}, \mathrm{Ba}$, $\mathrm{Pb}$. The values were given in $\mathrm{ng} / \mathrm{m}^{3}$. Depending on the element, the detection limit varied from 1 to $20 \mathrm{ng} / \mathrm{m}^{3}$, see Table S1 (Supplementary Material), and the uncertainty on the determination of the concentration was between 2 and 10\%. An EEL model 43 smoke stain reflectometer (Diffusion System Ltd.) (Adams et al. 2002) was used to determine black carbon concentration on the fine samples. Black carbon concentration data were given in $\mu \mathrm{g} / \mathrm{m}^{3}$ with a $10 \%$ measurement uncertainty. 


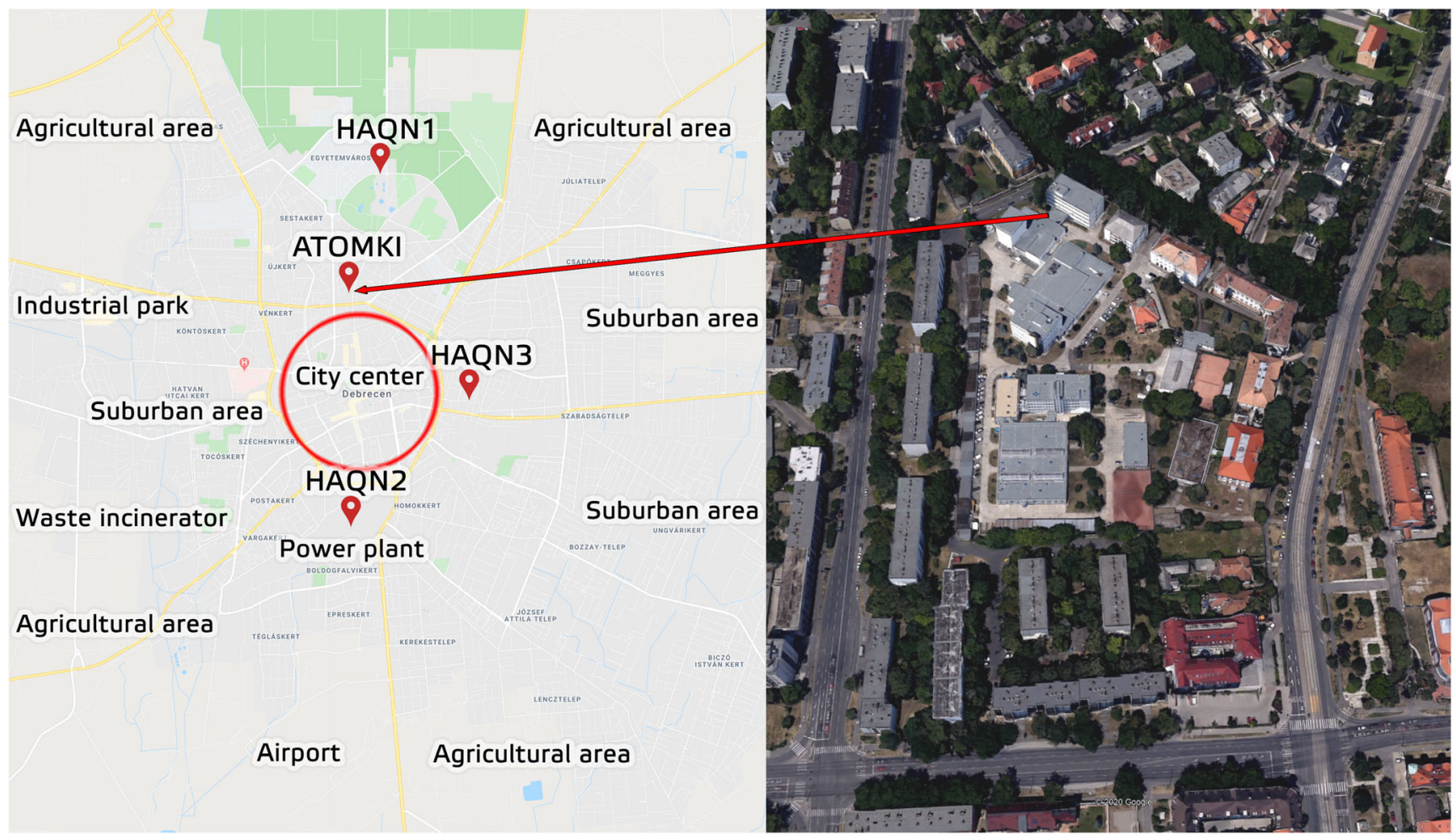

Fig. 1 Left: the city of Debrecen and a detailed map of the sampling site with the location of the sampling station and Hungarian Air Quality stations. Right: Expanded view of the sampling area

\section{Data analysis}

\section{Enrichment factor calculation}

In order to have an indication on the type of the sources of PM, the enrichment factor $(\mathrm{EF})$ of each element determined was calculated according to the following equation:

$\mathrm{EF}=\frac{\frac{X_{P M}}{S i_{P M}}}{\frac{X_{\text {Crust }}}{S i_{\text {Crust }}}}$

where $\mathrm{X}$ is the concentration of the element of interest and $\mathrm{Si}$ is the concentration of a reference element, which is predominately from natural origin and its mass is conserved. By convention, an $\mathrm{EF}<10$ is indicative of the elements' crustal origin, due to some uncertainty related to natural variation of crustal composition, while elements with $\mathrm{EF}>10$ are attributed as elements originated from anthropogenic sources. The EFs were calculated on the basis of the elemental concentrations on Earth's upper crust (Mason and Moore 1982).

\section{Numerical weather prediction model (WRF)}

An accurate description of the planetary boundary layer (PBL) height is important for the evaluation of air pollution situations. In our work, the Hungarian version of the Weather
Research and Forecasting (WRF) model was applied to determine the PBL height values, using the BouLac PBL scheme (Bougeault and Lacarrére 1989). The BouLac PBL scheme is classified as a one-and-a-half order turbulent kinetic energy (TKE) closure scheme which determines the diffusion coefficients from the prognostically calculated TKE (Szintai and Kaufmann 2008).

\section{Positive matrix factorization}

Apportionment of $\mathrm{PM}_{2.5}$ and $\mathrm{PM}_{\text {coarse }}$ sources was performed applying the EPA PMF 5.0 software (Paatero and Tapper 1994; Paatero 1997). A data set can be viewed as a data matrix $\mathrm{X}$ of $\mathrm{i}$ by $\mathrm{j}$ dimensions in which $\mathrm{i}$ number of samples and $\mathrm{j}$ chemical species were measured. The goal of the multivariate receptor models like PMF is to identify a number of factors $p$, the species profile $f$ of each source, and the amount of mass $g$ contributed by each factor to each individual sample:

$x_{i j}=\sum_{k=1}^{p} g_{i k} f_{k j}+e_{i j}$

where $\mathrm{e}_{\mathrm{ij}}$ is the residual for each sample/species.

The main advantages of PMF over the other traditional factor analysis methods (e.g. PCA) are that it includes nonnegativity constraints, it is capable of accommodate missing or below detection limit data, and the fact that every point in the matrix is individually weighted by its uncertainty. Non- 
negativity constraints are applied to PMF factors $g_{i k}$ and $f_{k j}$ to decrease rotational freedom and to produce factors with physical meaning, as a factor with negative contribution is not possible in this type of environmental studies. The optimum solution in PMF is the one that minimizes the objective function $\mathrm{Q}$, based on the uncertainties of each observation (Polissar et al. 2001). The function is defined as:

$Q=\sum_{i=1}^{n} \sum_{j=1}^{m}\left[\frac{X i j-\sum_{k=1}^{p} \text { gifkj }}{u i j}\right]^{2}$,

where $\mathrm{u}_{\mathrm{ij}}$ is an uncertainty estimate for $\mathrm{j}$-th constituent measured in the i-th sample.

Robust mode was applied to decrease the effects of data points with high residuals on the PMF solution. Values below the detection limit level (LOD) were replaced by $0.5 \times$ LOD and their uncertainties were set to $5 / 6$ of the LOD. Missing values were replaced by the mean concentration of the species considered, with an uncertainty of four times the concentration value.

Uncertainties originating from sampling and all analysis processes were taken into account. The overall uncertainty was calculated as square root of the sum of squares of individual errors:

$\mathrm{U}_{\mathrm{tot}}=\sqrt{\Sigma_{i} U_{i}^{2}}$

\section{Determination of the number of factors in PMF analysis}

In both the fine and coarse fractions, 153 samples were analysed, and all variables with more than $80 \%$ of values being below their detection limits $(\mathrm{P}, \mathrm{V}, \mathrm{Sr}, \mathrm{Ba}$ in fine and $\mathrm{V}, \mathrm{Br}, \mathrm{Ba}$ in coarse fractions) were excluded from the analysis. PMF analysis was carried out with extra modeling uncertainty $(10 \%)$ to achieve global minima. Due to their $\mathrm{S} / \mathrm{N}$ (signal to noise) ratio or high scaled residuals, $\mathrm{Al}, \mathrm{P}, \mathrm{Ti}, \mathrm{Cr}, \mathrm{Mn}, \mathrm{Ni}, \mathrm{Cu}$ and $\mathrm{Pb}$ were classified as weak in the coarse fraction and $\mathrm{Al}, \mathrm{Ti}$ and $\mathrm{BC}$ in the fine fraction. The model was run with different factor numbers (4-8) to identify the highest number of factors with physical meaning. The scaled residuals, the $\mathrm{Q}$ values and the resulting source profiles were examined. Based on the most physically reasonable result and adequate fit of the model to original data, seven factors in the fine fraction and five factors in the coarse fraction were considered as the optimal solution. Q/Qexp (Brown et al. 2015) (1.1 in the coarse and 1.0 in the fine fraction) and $r^{2}(0.93-0.99)$ between modeled and real concentrations showed that most samples and species were well modeled, except for the weak variables $\left(\mathrm{r}^{2} 0.38-0.80\right)$. All run converged, the scaled residuals were normally distributed between -3 and +3 . Although several values for Fpeak
(PMF parameter for rotational control) were tested, changing the Fpeak value did not result in better source profiles. Error estimation methods - classical bootstrap (BS), displacement of factor elements (DISP), and bootstrap enhanced by displacement (BS-DISP) — were applied to examine the stability of our solution. The results of the diagnostic tools offered by EPA PMF revealed that the solution was robust with low rotational ambiguity. Bootstrap results displayed that the factors were reproduced at the minimum level of $85 \%$ of the produced resamples and there were no swaps for the minimum dQ level with DISP, indicating well-defined factors. Some constraints were applied to the solution to apportion the right tracers to the factors. BC was set to zero in the soil factor as it is not expected to be present in a soil factor and was pulled up in the biomass burning factor. The overall dQ change after the application of the constraints was lower than $0.5 \%$, indicating that no significant differences with respect to the unconstrained results occurred in the solution.

\section{Conditional probability function}

Impacts from various wind directions were assessed through calculating the conditional probability function (CPF) which couples source contribution estimates from receptor modeling with wind directions measured on the site (Kim et al. 2003). The CPF is defined as:

$C P F_{\Delta \theta}=\frac{m_{\Delta \theta}}{n_{\Delta \theta}}$

where $m_{\Delta_{\theta}}$ is the number of occurrence from the wind sector $\Delta \theta$ that exceeded the threshold criterion, $n_{\Delta_{\theta}}$ is the total number of data records from the same wind sector. Calm winds (< $1 \mathrm{~m} / \mathrm{s}$ ) were excluded from the analysis due to the isotropic behaviour of wind vane under calm conditions. The threshold criterion was set at the upper 10th percentile value of the source contributions for each source. The sources are likely to be located in directions that have high conditional probability values. Polar plots were obtained applying the $\mathrm{R}$ Openair Package (Carslaw and Ropkins 2012).

\section{Results and discussion}

\section{Atmospheric condition, $\mathrm{PM}_{2.5}, \mathrm{PM}_{10}$ and $\mathrm{NO}_{\mathrm{x}}$}

At the end of October, 2011, an anticyclone extended over Central Europe and the impact of a high pressure weather system was dominant in the following weeks. The European weather situation is presented in Fig. 2 at the beginning of the smog period (21 October, 2011) and on 17 November, 2011, when the highest $\mathrm{PM}_{10}$ was measured in Debrecen. 


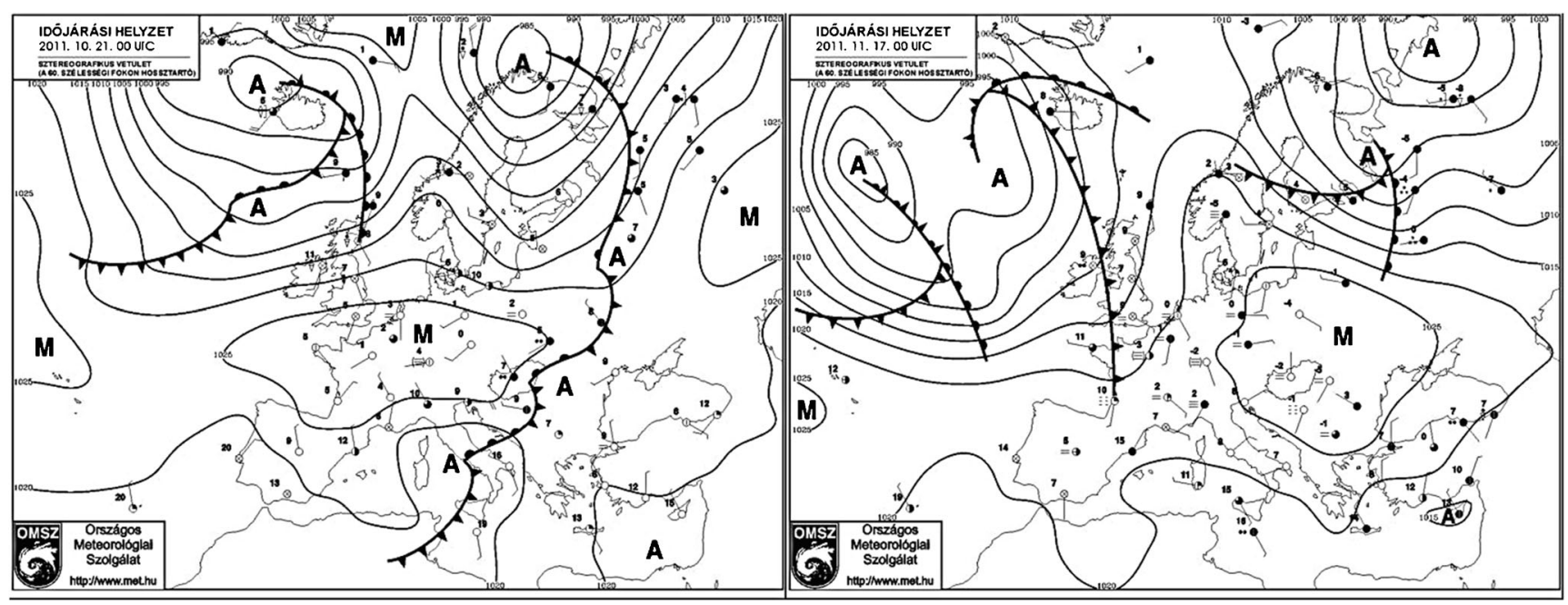

Fig. 2 European weather situation is shown at the beginning of the smog period (left) and on November 17, 2011, (right) when the highest PM ${ }_{10}$ was measured in Debrecen

It is apparent from both maps that an anticyclone over Europe controlled the weather in Hungary in those days and remained unchanged until the end of November. The weather was uneventful, variably cloudy and foggy at some places. During these days, the wind speed was very low and there was no precipitation around Debrecen. Due to the meteorological condition, the concentration of $\mathrm{PM}_{10}$ increased from 25 October.

At the Atomki site, 24-h $\mathrm{PM}_{2.5}$ and $\mathrm{PM}_{2.5-10}$ samples have been collected two times a week since 1998 (Furu et al. 2015). Figure 3 shows the measured $\mathrm{PM}_{2.5}$ and $\mathrm{PM}_{10}$ concentrations at Atomki and the $\mathrm{PM}_{10}$ concentrations measured at the 3 HAQN stations of Debecen during 2011. The investigated high pollution level period is clearly shown. Unfortuantely due to a temporary failure of the sampler, PMcoarse and thus $\mathrm{PM}_{10}$ concentrations are not available for 10 of October to 15 of November.

In general, at Atomki, lower $\mathrm{PM}_{10}$ concentrations were measured when compared to the values reported by the HAQN stations. It has been indicated in several studies in the past that there are differences between automatic (as in HAQN stations) and standard off-line PM mass concentration measurements (Shin et al. 2011; Takahashi et al. 2008), with higher deviation at high ambient RH (Chang and Tsai 2003). Additionally, 24-h PM measurements can be significantly influenced by the interaction of water with the filter material and/or aerosol particles during collection under unfavourable weather conditions. Having that said, our $\mathrm{PM}_{10}$ concentration values correlate well with the $\mathrm{PM}_{10}(\mathrm{r}=0.74, p<0.01)$ values of HAQN1 and of HAQN2 $(r=0.78, p<0.01)$, see Table S2 (Supplementary Material). Consequently, the hourly data from the monitoring station (HAQN1) were used for the study of the smog periods since this station is the one in closest proximity to the sampling point. $\mathrm{PM}_{10}$ and $\mathrm{NO}_{\mathrm{X}}$ trends recorded at HAQN1 and the variation of meteorological variables from October to December 2011, including the smog episodes, are illustrated in Fig. 4.

The average $\mathrm{PM}_{10}$ concentration during the sampling campaigns at HAQN1 was $80.95 \pm 45.44 \mu \mathrm{g} / \mathrm{m}^{3}$, with a peak up to $344 \mu \mathrm{g} / \mathrm{m}^{3}$ on November $17,11 \mathrm{pm}$, registered with southwest (SW) wind direction. The average concentrations of the gaseous pollutants during the campaign were $69.80 \pm 69.23$ $\mu \mathrm{g} / \mathrm{m}^{3}$ for $\mathrm{NO}_{\mathrm{x}}, 47.62 \pm 33.74 \mu \mathrm{g} / \mathrm{m}^{3}$ for $\mathrm{NO}_{2}, 14.51 \pm 26.18$ $\mu \mathrm{g} / \mathrm{m}^{3}$ for NO and $963.18 \pm 558.59 \mu \mathrm{g} / \mathrm{m}^{3}$ for CO (Fig. S1 in Supplementary Material). Moderate correlation ( $\mathrm{r}=0.57, p<$ 0.01) was found between the $\mathrm{PM}_{10}$ and $\mathrm{NO}_{\mathrm{x}}$ concentrations during the smog periods. There was no rain reported during the sampling periods, and the relative humidity ranged from 38 to $96 \%$, but was mostly above $70 \%$. Winds from the first quadrant $\left(0-90^{\circ}\right)$ were the most characteristic, 52\% during the campaign, and had the highest average WS (wind speed) (1.83 $\mathrm{m} \mathrm{s}^{-1}$ ).

The sampling period from 2 to 8 November was characterized by an average temperature of $7.64 \pm 4.99{ }^{\circ} \mathrm{C}$, wind speed of $1.46 \mathrm{~m} \mathrm{~s}^{-1}$ in average, wind direction prevailing from $\mathrm{N}$ to $\mathrm{E}$ and high $\mathrm{PM}_{10}$ level of $86.04 \pm 28.50 \mu \mathrm{g} / \mathrm{m}^{-3}$. The $\mathrm{PM}_{10}$ and $\mathrm{NO}_{\mathrm{x}}$ concentrations decreased on 10-11 November, corresponding to a change in wind direction and an increased wind speed. The sampling period from 15 to 21 November was characterized by lower temperatures $\left(-0.36 \pm 2.80{ }^{\circ} \mathrm{C}\right)$, an average wind speed of $1.69 \mathrm{~m} \mathrm{~s}^{-1}$, with the WD changing from $\mathrm{S}$ to $\mathrm{N}$ and $\mathrm{PM}_{10}$ concentrations of $76.31 \pm 57.92 \mu \mathrm{g} / \mathrm{m}^{-3}$.

\section{Variation of the PBL height}

Figure 5 presents the PBL height during the sampling campaigns. The PBL height ranged from 44 to $759 \mathrm{~m}$ with an average of $140 \mathrm{~m}$ for 2 to 8 November while it ranged from 44 to $730 \mathrm{~m}$ with the average of $194 \mathrm{~m}$ from 15 to 21 November. Due to the changing meteorological parameters 
Fig. 3 PM mass concentrations measured at Atomki and PM10 concentration measured by Hungarian Air Quality Network stations in November 2011

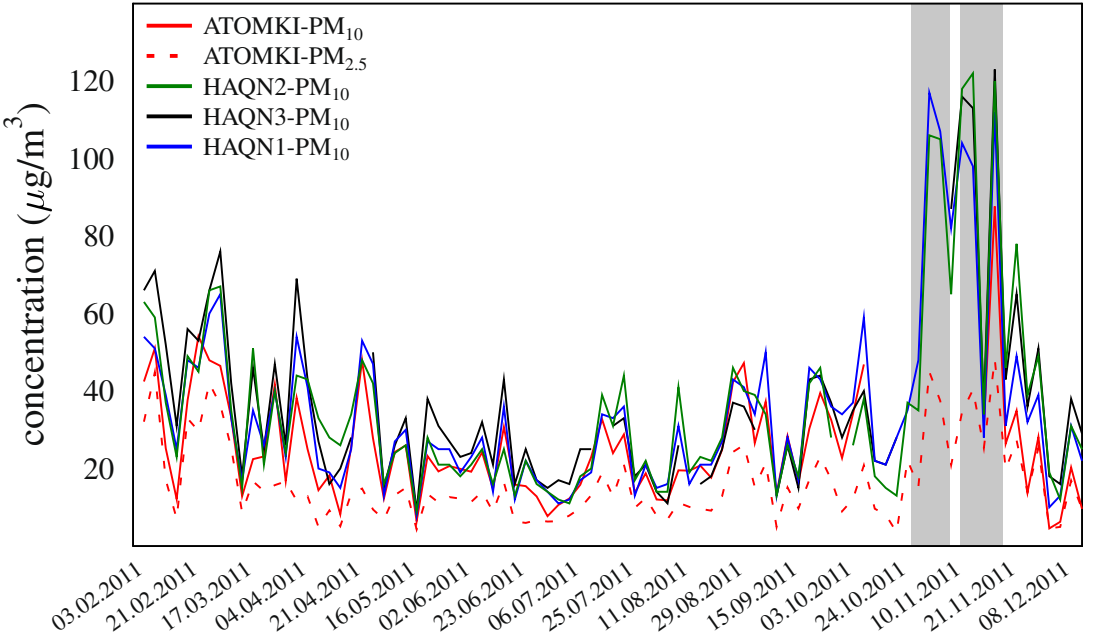

(temperature, humidity, planetary-boundary-layer), from 15 November, the height and the dynamics of PBL shifted: the minimum was at $1 \mathrm{am}$, the maximum was at $11 \mathrm{am}$ while previously the minimum was at $5 \mathrm{am}$, the maximum at 1 pm. Along with increasing surface pressure and decreasing temperature and wind speed, a high level of PM10 was measured on 17 November, 11 p.m. when the highest PBL height was only $160 \mathrm{~m}$ during the day. Consequently, the emitted compounds could not be effectively diluted with the ambient air. This unfavourable meteorological situation could lead to
Fig. 4 Temporal variation of meteorological parameters ( $T$, $\mathrm{RH}, \mathrm{P}, \mathrm{WS}, \mathrm{WD}), \mathrm{PM}_{10}$ and NOx from October to December 2011

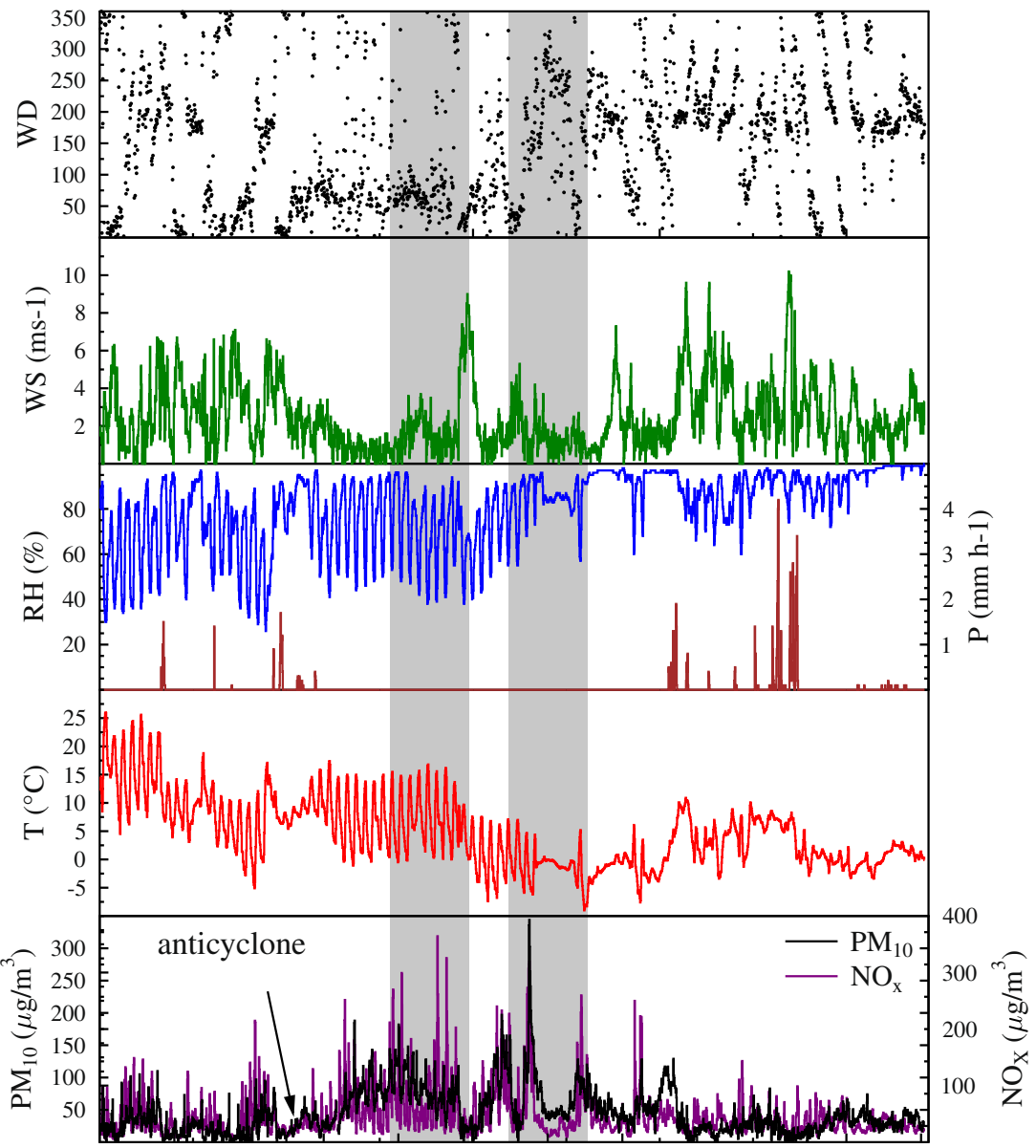

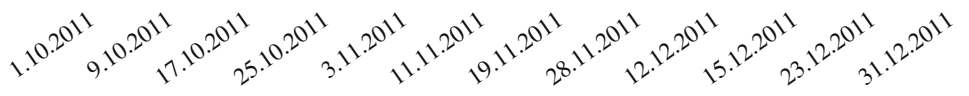



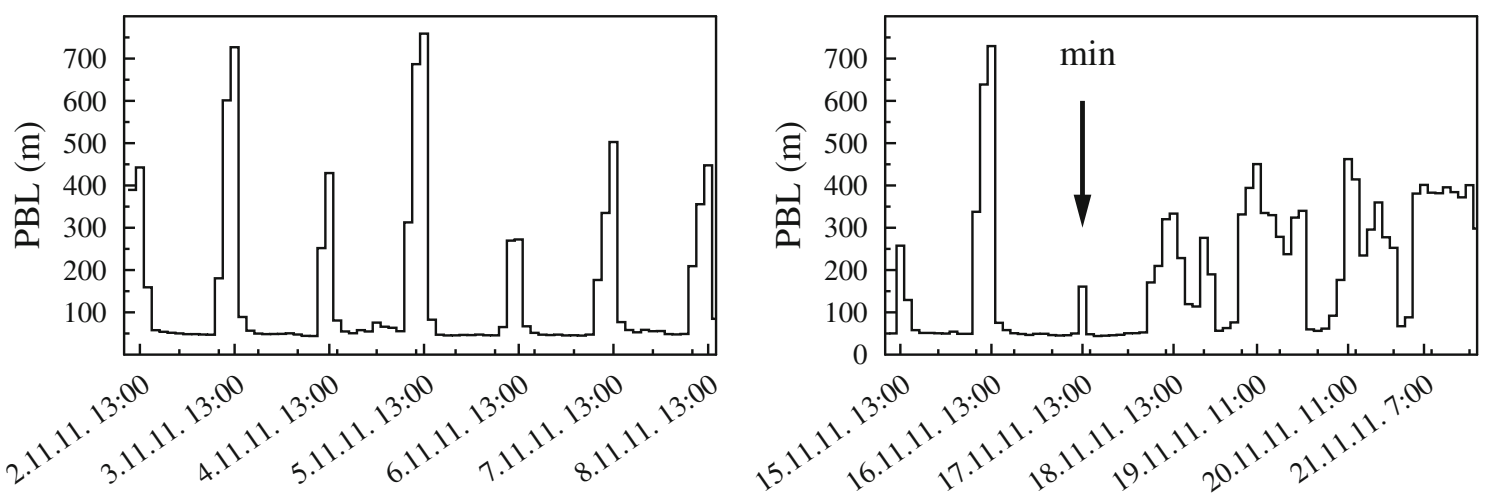

Fig. 5 Planetary boundary layer (PBL) height from 2 to 8 and from 15 to 21 October in Debrecen

the high accumulation of aerosol concentrations. On this day, the maximum $\mathrm{PM}_{10}$ concentration was observed at all monitoring sites.

\section{Elemental concentrations}

The elemental concentrations for the study period are presented in Table 1.

The mean concentrations of S $\left(2326 \pm 604 \mathrm{ng} / \mathrm{m}^{3}\right), \mathrm{K}(583$ $\left.\pm 490 \mathrm{ng} / \mathrm{m}^{3}\right)$ and $\mathrm{BC}\left(6866 \pm 4655 \mathrm{ng} / \mathrm{m}^{3}\right)$ were $2-3$ times higher in the $\mathrm{PM}_{2.5}$ fraction than the previously reported results from the same location (Kertész et al. 2010). The increase in the concentrations of $\mathrm{Cr}, \mathrm{Cu}$ and $\mathrm{Ni}$ was caused by the tramline construction which took place near the sampling station in 2011 (Furu et al. 2015).

To assess the effect of anthropogenic emissions to the observed concentrations of the elements, the enrichment factors (EFs) were estimated. EF was between 1 and 10 for both size fractions in the case of the mineral dust elements like $\mathrm{Ca}$, $\mathrm{Ti}$, $\mathrm{Mn}, \mathrm{Fe}$, indicating that they could originate from soil and soil resuspension (Salma et al. 2001). Furthermore, elements (S, $\mathrm{K}, \mathrm{Zn}$ and $\mathrm{Pb}$ ) generally associated with anthropogenic emissions according to their estimated EFs $(>10)$, were found predominantly in the fine size fraction, see the average $\mathrm{PM}_{2.5} / \mathrm{PM}_{\text {coarse }}$ ratios. Nevertheless, $\mathrm{Cl}, \mathrm{Ni}$ and $\mathrm{Cu}$ had high EFs in both size fractions and their $\mathrm{PM}_{2.5} / \mathrm{PM}_{\text {coarse }}$ ratios were around 1. This fact indicates that these elements are emitted in both coarse and fine modes by their sources. In our previous study (Angyal et al. 2010), we could identify the following anthropogenic sources of coarse mode $\mathrm{Cl}$ : winter salting of streets, agriculture through fertilizers, buildings construction and industry.

\section{Elemental composition of PM mass size distributions}

Elemental mass size distributions were determined for 17 elements using the results obtained by the cascade impactor for the sampling periods 2-5, 7-9 and 15-17 November 2011 (Fig. 6).
Basically, four different kinds of particles could be identified during these smog periods based on the size distribution. (1) Species typically associated with mineral dust such as $\mathrm{Al}, \mathrm{Si}, \mathrm{Ca}, \mathrm{Ti}, \mathrm{Mn}, \mathrm{Fe}$ and $\mathrm{Ba}$ were observed in the coarse fraction with a dominant peak at the $4-8 \mu \mathrm{m}$ range on 2-5 November. It is likely that these elements were formed by mechanical processes such as resuspension of soil or road dust (Seinfeld and Pandis 1998). (2) Furthermore, some anthropogenic components showed a remarkable contribution in the droplet mode $(0.5-1 \mu \mathrm{m})$. The elevated $\mathrm{S}$ concentration and the high fraction of sulphur in the droplet mode particles point to the intensive secondary particle formation of droplet mode sulphate under smog episodes. At the same time, condensation-mode sulphur $(0.25-0.5 \mu \mathrm{m})$ showed only a slight peak. $\mathrm{Zn}$ and $\mathrm{Pb}$ were also found to be present in high concentrations in the droplet mode, their possible sources include traffic, industrial emission (Moffet et al. 2008) and waste incineration (Ogulei et al. 2006). (3) Other species like $\mathrm{K}$ and $\mathrm{Cl}$ which are associated with combustion processes had one prevalent peak in the droplet mode $(0.5-1 \mu \mathrm{m})$ and another lower peak at the $4-8 \mu \mathrm{m}$ range. This bimodal shape indicates that these elements have at least two different sources. At the beginning of smog periods, potassium exhibited a peak also in the condensation mode $(0.25-0.5 \mu \mathrm{m})$, implying freshly emitted particles. When potassium is emitted from biomass burning, it is mainly in the form of $\mathrm{KCl}$ (Jöller et al. 2007) in the fine fraction. (4) Finally, erratic size distributions for several elements $(\mathrm{Cu}$, $\mathrm{Cr}$ and $\mathrm{Ni}$ ) were attributed to variable influence of emission sources including a nearby road and a tramline construction.

From November 7, the dominant peak in the coarse mode was shifted. The concentration of most elements increased at the 8-16 $\mu \mathrm{m}$ range, of which $\mathrm{Al}, \mathrm{Si}, \mathrm{P}, \mathrm{Ca}, \mathrm{S}, \mathrm{K}$, $\mathrm{Cl}, \mathrm{Ca}, \mathrm{Ti}, \mathrm{Cr}, \mathrm{Mn}, \mathrm{Fe}, \mathrm{Cr}, \mathrm{Ni}, \mathrm{Cu}$ and $\mathrm{Zn}$ concentrations increased approximately sixfold on 7-9 November. This points to the significance of the local dust resuspension processes in Debrecen. 
Table 1 Elemental

concentrations (average $\pm \mathrm{SD}$, ng/ $\mathrm{m}^{3}$ ), enrichment factors $(\mathrm{EF})$ and mean $\mathrm{PM}_{2.5}$-to-PM $\mathrm{PMarse}_{\text {concen- }}$ tration ratios during the smog episodes

\begin{tabular}{|c|c|c|c|c|c|}
\hline$N=153$ & $\begin{array}{l}\mathrm{PM}_{2.5}(\mathrm{ng} / \\
\left.\mathrm{m}^{3}\right)\end{array}$ & $\mathrm{EF}$ & $\begin{array}{l}\mathrm{PM}_{\text {coarse }}(\mathrm{ng} / \\
\left.\mathrm{m}^{3}\right)\end{array}$ & $\mathrm{EF}$ & $\begin{array}{l}\text { PM2.5/ } \\
\text { PMcoarse }\end{array}$ \\
\hline $\mathrm{Al}$ & $42 \pm 25$ & 1 & $13 \pm 17$ & 1 & 3.2 \\
\hline $\mathrm{Si}$ & $155 \pm 38$ & & $294 \pm 77$ & & 0.5 \\
\hline $\mathrm{P}$ & $<\mathrm{DL}$ & & $27 \pm 9$ & 22 & \\
\hline $\mathrm{S}$ & $2326 \pm 604$ & 11651 & $142 \pm 166$ & 580 & 16.3 \\
\hline $\mathrm{Cl}$ & $22 \pm 23$ & 313 & $62 \pm 85$ & 485 & 0.4 \\
\hline K & $583 \pm 490$ & 41 & $71 \pm 61$ & 3 & 8.2 \\
\hline $\mathrm{Ca}$ & $31 \pm 25$ & 2 & $212 \pm 56$ & 6 & 0.1 \\
\hline $\mathrm{Ti}$ & $3 \pm 2$ & 1 & $8 \pm 6$ & 2 & 0.4 \\
\hline $\mathrm{V}$ & $<\mathrm{DL}$ & & $<\mathrm{DL}$ & & \\
\hline $\mathrm{Cr}$ & $5 \pm 1$ & & $4 \pm 1$ & & 1.1 \\
\hline $\mathrm{Mn}$ & $3 \pm 1$ & 5 & $3 \pm 1$ & 3 & 0.9 \\
\hline $\mathrm{Fe}$ & $75 \pm 52$ & 3 & $106 \pm 51$ & 2 & 0.7 \\
\hline $\mathrm{Ni}$ & $5 \pm 1$ & 99 & $4 \pm 1$ & 59 & 1.2 \\
\hline $\mathrm{Cu}$ & $5 \pm 3$ & 155 & $8 \pm 5$ & 138 & 0.6 \\
\hline $\mathrm{Zn}$ & $40 \pm 45$ & 766 & $12 \pm 12$ & 171 & 3.3 \\
\hline $\mathrm{Br}$ & $16 \pm 4$ & & $<\mathrm{DL}$ & & \\
\hline $\mathrm{Sr}$ & $<\mathrm{DL}$ & & $12 \pm 5$ & & \\
\hline $\mathrm{Ba}$ & $<\mathrm{DL}$ & & $<\mathrm{DL}$ & & \\
\hline $\mathrm{Pb}$ & $29 \pm 26$ & 3026 & $15 \pm 8$ & 1205 & 1.9 \\
\hline $\mathrm{BC}$ & $6866 \pm 4655$ & & & & \\
\hline
\end{tabular}

\section{Source apportionment of $\mathbf{P M}_{2.5}$ and $\mathrm{PM}_{\text {coarse }}$}

PMF factor profiles and their relative contribution, together with planetary-boundary-layer height, for $\mathrm{PM}_{2.5}$ and $\mathrm{PM}_{\text {coarse }}$ are shown in Fig. 7 and Fig. 8, respectively, while the percentage of relative source contributions to $\mathrm{PM}_{2.5}$ and $\mathrm{PM}_{\text {coarse }}$ by source category is in Fig. 9. The CPF plot for the highest 10\% contributions from PMF factors can be see in Fig. 10. The dominant winds were from the NNE to the E.

The factors were identified as soil (Factor F1), waste incineration (Factor F2), tram traffic (Factor F3), biomass burning (Factor F4), secondary sulphate (Factor F5), tramline
Fig. 6 Mass size distribution of elements (sampling dates: $2-5,7$ 9 and 15-17 November, 2011)
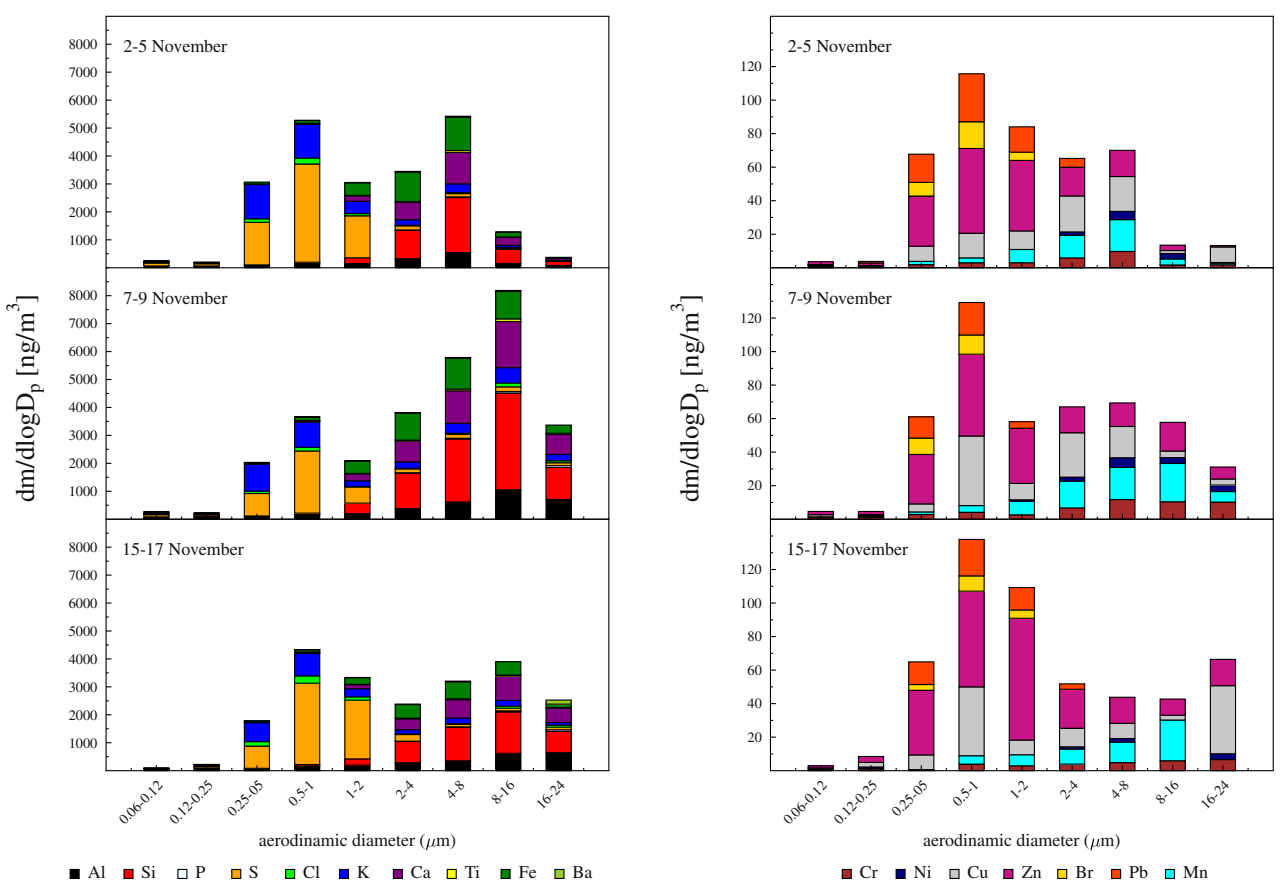

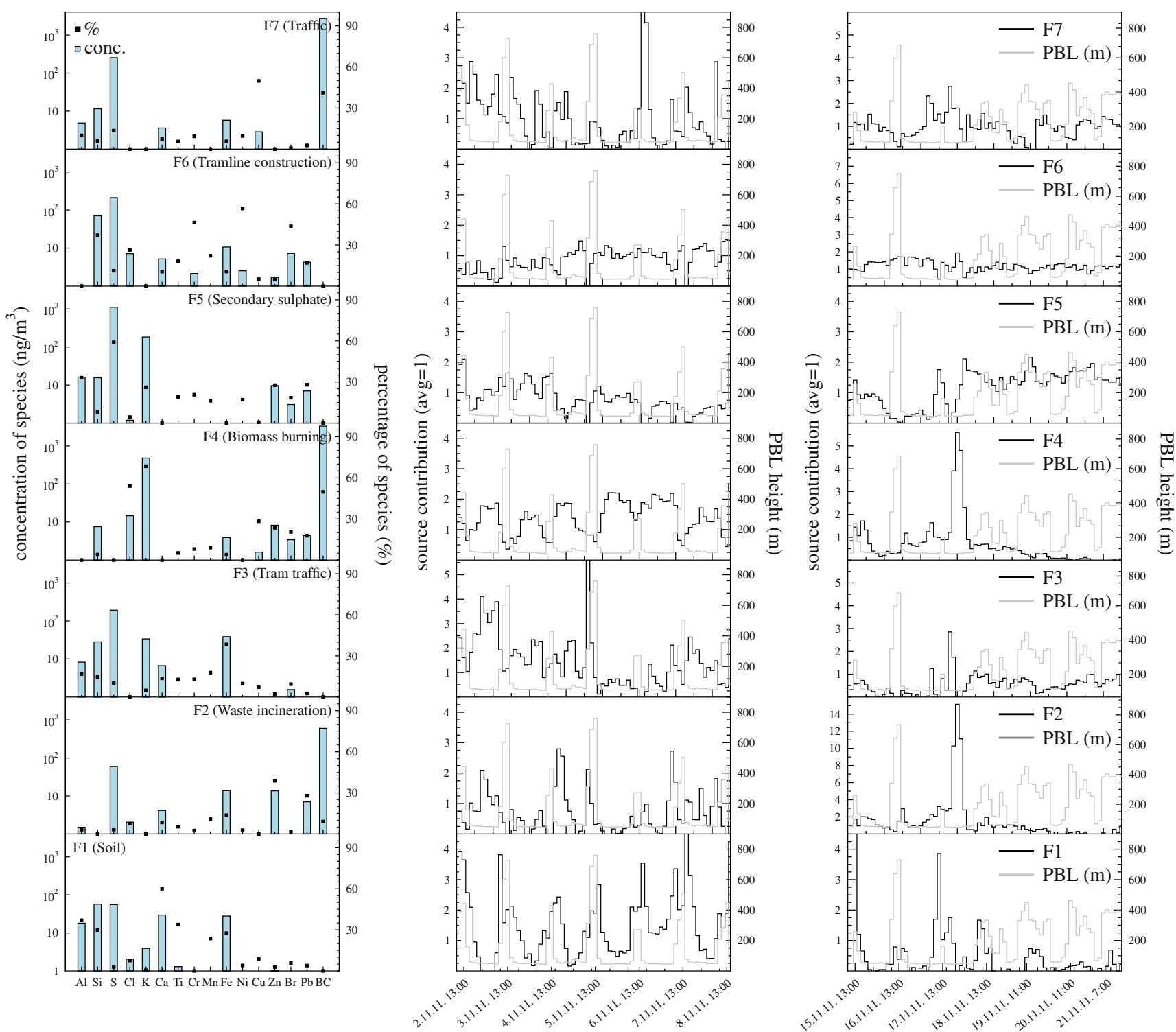

Fig. 7 Source profiles and time series plots of the source contribution together with planetary boundary layer height calculated by WRF in the fine fraction

construction (Factor F6) and traffic (Factor F7) in the fine fraction, while soil (Factor $\mathrm{C} 1$ ), traffic (Factor $\mathrm{C} 2$ ), coal combustion (Factor C3), tramline construction with soil (Factor C4) and agricultural through fertilizer with biomass burning (Factor C5) were recognised in $\mathrm{PM}_{\text {coarse. }}$ Based on the sum of the measured elemental concentrations in each factor, the contribution was estimated. For the calculation of the contribution of the sources, the external mass method was used, i.e. $\mathrm{PM}_{2.5}$ mass concentration was not used in the input matrix. The measured mass was regressed against the source contribution values. Even though there is a difference between the sum of the mass of the single chemical components and the $\mathrm{PM}_{2.5}$ concentration, this method can provide an estimate about the source contribution when PM concentration is not available. Furthermore, the average factor contributions of working days and weekends (5-6 November and 19-20 November) were also examined.
The first factor profile in $\mathrm{PM}_{2.5}$ was identified as soil. The major constituents were $\mathrm{Ca}(60.0 \%), \mathrm{Al}(37.0 \%), \mathrm{Fe}(27.6 \%)$ and $\mathrm{Si}(29.9 \%)$, which are well-known tracers of soil (Diapouli et al. 2016; Psanis et al. 2017). The CPF plot primarily pointed to the nearby streets and the relative contribution to $\mathrm{PM}_{2.5}$ was $2 \%$. Factor $\mathrm{F} 2$ was characterized by the high amount of $\mathrm{Pb}(27.9 \%), \mathrm{Zn}(38.8 \%)$ and $\mathrm{BC}(9.0 \%)$. This factor could reasonably be interpreted as a waste incineration source, as those tracers are found to represent this source in previous studies (Moffet et al. 2008). The $\mathrm{Zn} / \mathrm{Pb}$ ratio was equal to 1.9 for this factor and it is close to 1.8 , a reported ratio for an municipal incinerator emissions (Polissar et al. 2001). Source assignment of waste incineration was supported by the low contribution during the weekends. The higher contribution was observed during evening hours and mornings. The relative contribution of this factor to $\mathrm{PM}_{2.5}$ mass was $7 \%$. This 

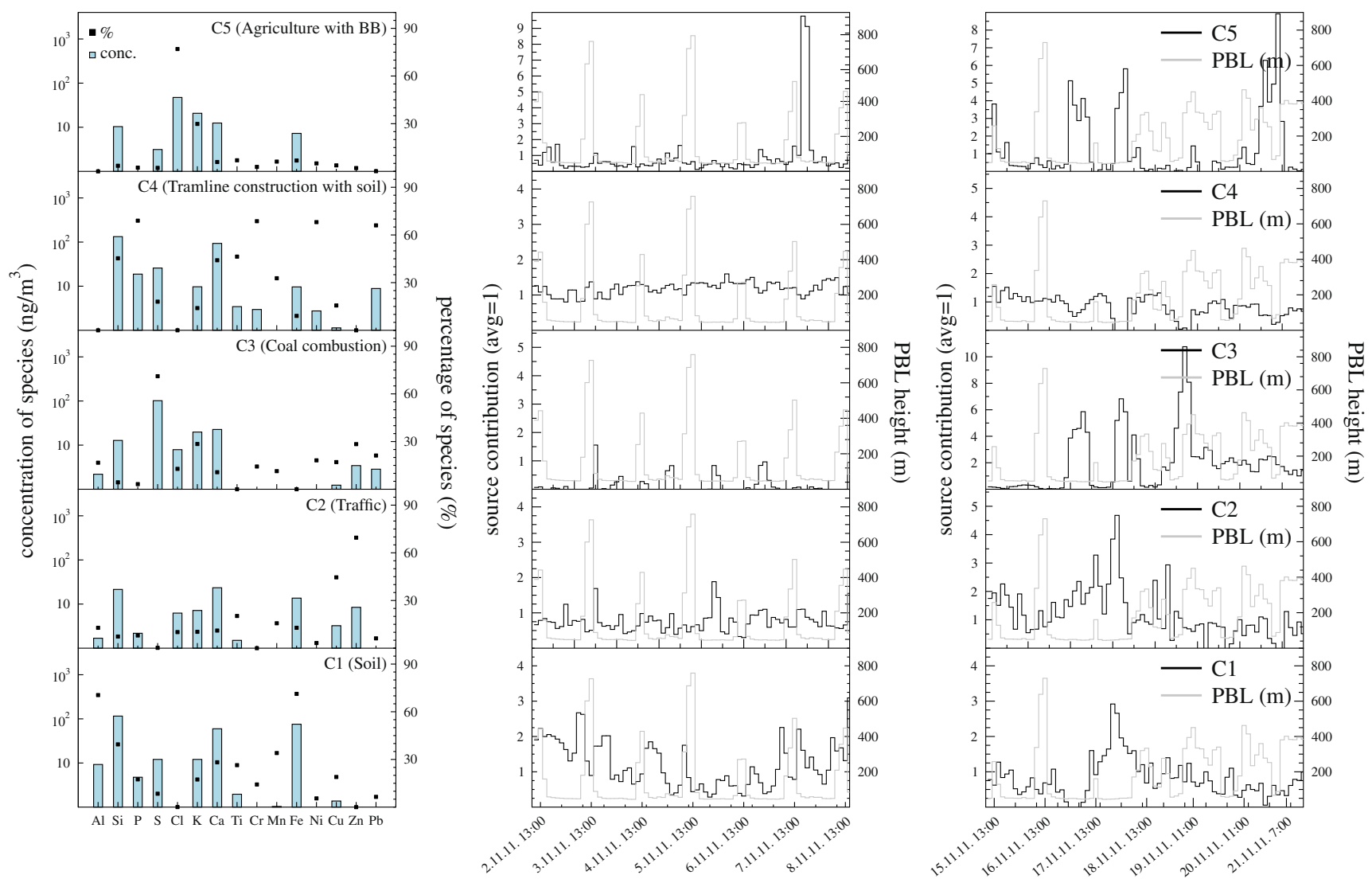

Fig. 8 Source profiles and time series plots of source contribution together with planetary boundary layer height calculated by WRF in the coarse fraction

factor showed moderate correlation (see Table S3 in Supplementary Material) with $\mathrm{CO}(\mathrm{r}=0.68, p<0.01)$, with $\mathrm{NO}_{\mathrm{x}}(\mathrm{r}=0.56, p<0.01)$ and with $\mathrm{PM}_{10}(\mathrm{r}=0.47, p<0.01)$ confirming the combustion origin. The closest municipal incinerator to the site was situated in 2011 less than $7 \mathrm{~km}$ at $220^{\circ}$, which corresponds to the direction suggested by the $\mathrm{CPF}$ analysis. Factor F3 was loaded with Fe and Mn. The possible origin of this factor was the tram traffic in Debrecen as $\mathrm{Fe}$ and $\mathrm{Mn}$ are known tracers from the abrasion of the stainless steel trucks of tram lines and metro/train lines (Martins et al. 2021, 2015). The $\mathrm{Mn} / \mathrm{Fe}$ ratio was 0.01 in this factor which is highly consistent with an origin from steel used in wheels, rails and brakes (Moreno at al. 2014; Abbasi et al. 2012). The diurnal variation was clearly observed: higher
Fig. 9 Percentage of relative source contributions to $\mathrm{PM}_{2.5}$ and $\mathrm{PM}_{\text {coarse }}$ by source category
$\mathrm{PM}_{2.5}$ contribution

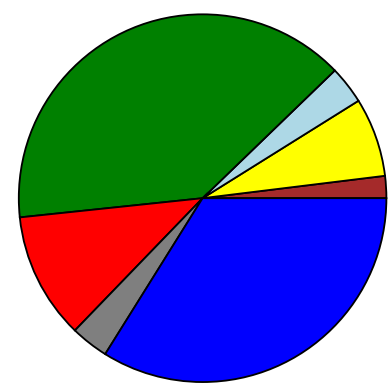

$2 \%$ Soil $7 \%$ Waste incineration $\square$ 3\% Tram traffic

$\square$ 39\% Biomass burning - $15 \%$ Secondary sulphate $\square \quad 3 \%$ Tramline construction $31 \%$ Traffic
$\mathrm{PM}_{\text {coarse }}$ contribution

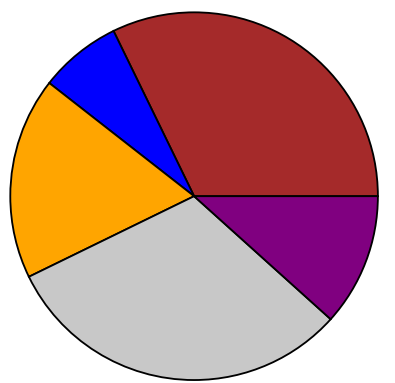

$32 \%$ Soil

- $9 \%$ Traffic

$\square 18 \%$ Coal combustion

$\square 30 \%$ Tramline construction with soil $\square 11 \% \mathrm{Cl}$ 


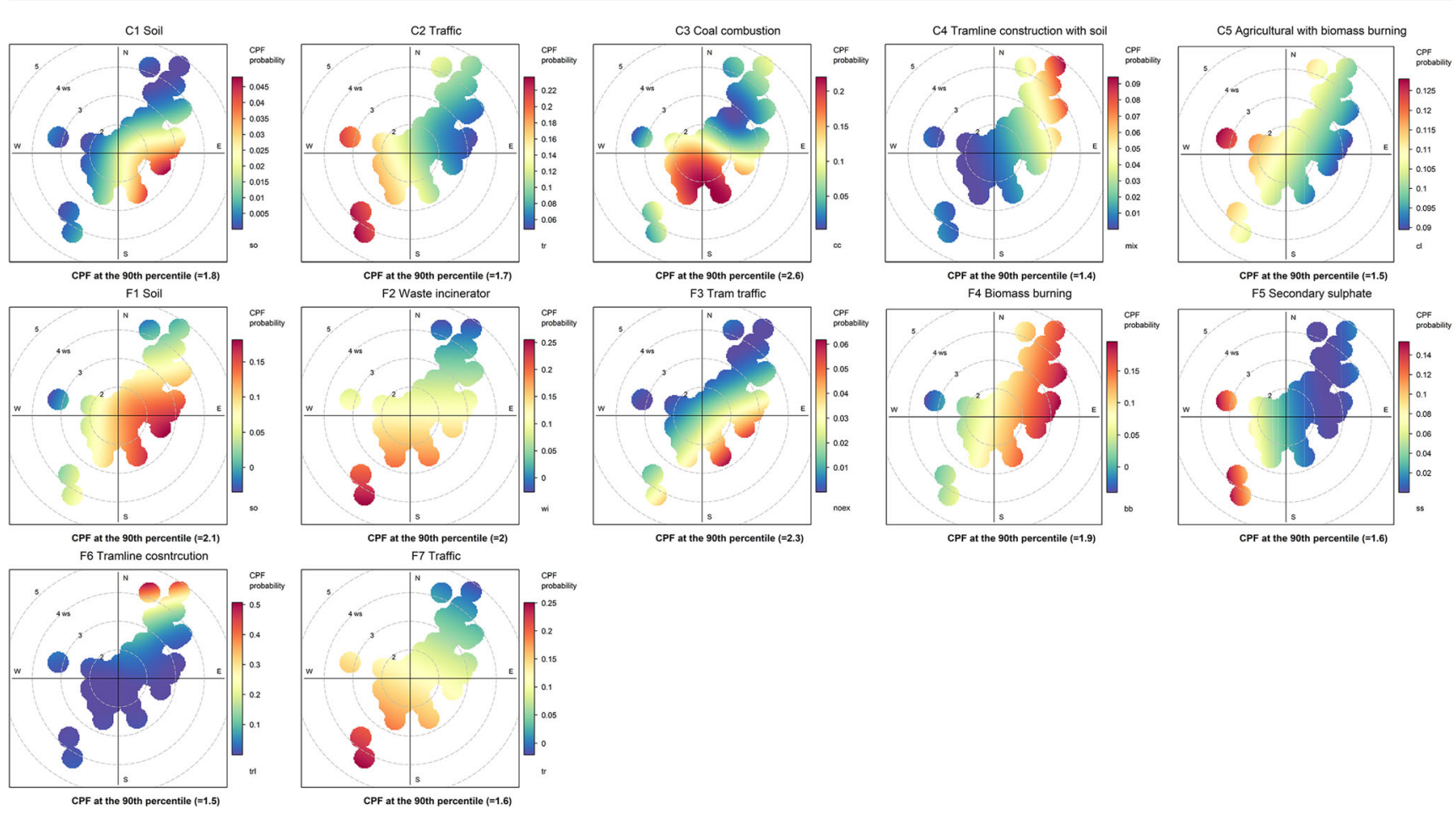

Fig. 10 Polar plots of $\mathrm{PM}_{2.5}$ and $\mathrm{PM}_{\text {coarse }}$ source contributions based on the CPF calculations. Wind speed (m/s) is displayed on the radius while the calculated probability is designated by colour

contributions in mornings and evenings. The CPF plot was corresponding to the directionality of soil which may suggest that this factor originated from a mixed source of road dust and tram traffic (Kertész et al. 2010). Factor F4 was characterized by a high amount of $\mathrm{K}(68.5 \%), \mathrm{Cl}(54.0 \%)$ and a significant amount of BC (49.7\%). Alongside BC, potassium is typically known as a tracer for biomass burning which comprises contributions from residential wood burning, burning of agricultural lands, other biomass waste and wildfires (Belis et al. 2019; Manousakas et al. 2021). The diurnal pattern of the source contribution of this factor was similar during the whole campaign. It showed large contributions during the night, opposite to the variation pattern of the planetary boundary layer. It was confirmed by the moderate negative correlation $(\mathrm{r}=-$ $0.46, p<0.01$ ) between biomass burning and PBL. The factor dominated during the smog episodes and contributed $39 \%$ of $\mathrm{PM}_{2.5}$. It had a positive moderate correlation with $\mathrm{NO}_{\mathrm{x}}, \mathrm{CO}$ and $\mathrm{PM}_{10}(\mathrm{r}=0.53, p<0.01),(\mathrm{r}=0.63, p<0.01),(\mathrm{r}=0.54, p$ $<0.01$ ), respectively. The CPF plot pointed from the northeast to the east, which corresponds to the location of the suburban area. Factor F5 has sulphur (63.1\%) as a main component, and thus it was recognised as secondary sulphate, which is consistent with previous publications (Amato et al. 2016). $\mathrm{SO}_{2}$ is the precursor of sulphate in particulate matter. $\mathrm{SO}_{2}$ can originate from diesel engine emissions, combustion of different types of fuels (oil, natural gas, pellets) or industrial emissions. The $\mathrm{SO}_{4}{ }^{2-}$ can occasionally be found together with $\mathrm{NH}_{4}{ }^{+}$and $\mathrm{Na}, \mathrm{OC}$ and $\mathrm{K}$ or trace metals such as $\mathrm{Cu}, \mathrm{Zn}$ and $\mathrm{Pb}$
(Viana et al. 2008). Due to its formation time, it is difficult to differentiate between locally emitted/formed secondary aerosol and transported secondary aerosol. The CPF plots indicated western contributions where an industrial park and another suburban area are located. This is a clear indication of the effect of local sources on the concentration levels of the secondary factor. The relative contribution to $\mathrm{PM}_{2.5}$ was $15 \%$. Factor F6 was characterized by the presence of $\mathrm{Cr}(45 \%)$ and Ni (55\%). The association of these elements with emission by the railroad building has been already emphasized by Furu et al. 2015 in Debrecen. Factor contribution to $\mathrm{PM}_{2.5}$ was $3 \%$ and it was constant apart from a minor diurnal variation. The polar plot showed a contribution from the north-east of the city where the tramline reconstruction works took place during the campaigns. Due to the dominance of species $\mathrm{Cu}$ (49.8\%) and BC (41.2\%), the Factor F7 was recognised as traffic (Viana et al. 2008). BC was associated with diesel vehicles (Swietlicki et al. 1996) exhaust and $\mathrm{Cu}$ with brake abrasion. This factor showed similar daily pattern to the soil factor during the campaigns. The CPF plot primarily pointed to the southwest where the city centre is situated. It contributed $31 \%$ to the $\mathrm{PM}_{2.5}$ mass concentration. This factor showed a moderate correlation $(\mathrm{r}=0.56, p<0.01),(\mathrm{r}=0.45, \mathrm{r}<0.01),(\mathrm{r}=$ $0.47, p<0.01),(\mathrm{r}=0.56, p<0.01)$ with $\mathrm{CO}, \mathrm{NO}_{\mathrm{x}}$ and $\mathrm{PM}_{10}$, respectively. Regarding the sources of traffic and waste incineration, despite the same direction, i.e. from the receptor site to the south-west, their time-series showed different variations during the investigated smog periods. 
The first factor (C1) in $\mathrm{PM}_{\text {coarse }}$ was characterized by high $\mathrm{Al}(70.5 \%)$ and other soil minerals ( $\mathrm{Si}(39.5 \%), \mathrm{Ca}(28.2 \%)$, $\mathrm{Fe}(71.2 \%)$ ) and its $32 \%$ relative contribution to the coarse fraction. The diurnal pattern of this factor and the CPF showed similarities with the soil factor in $\mathrm{PM}_{2.5}$. The second factor $\mathrm{C} 2$, assigned to traffic, contained $45 \%$ of all $\mathrm{Cu}$ and $69 \%$ of $\mathrm{Zn}$. $\mathrm{Cu}$ was associated with brake abrasion, $\mathrm{Zn}$ is a tracer of tire wear abrasion of cars or lubricating oil (Santoso et al. 2011; Minguillón et al. 2012). The diurnal pattern and the CPF showed similarities with the traffic factor in $\mathrm{PM}_{2.5}$. The $\mathrm{S}$ content $(71.1 \%)$ was the highest in Factor 3 (C3) in the coarse fraction. Furthermore, $28.4 \%$ of $\mathrm{Zn}$ and $28.5 \%$ of K were present here. These species combined could be regarded as tracers of coal combustion (Pernigotti et al. 2016). The time trend of this factor showed higher contribution during nights at the weekends. The factor contributed $18 \%$ to the coarse fraction. The directionality of this source extended from the southeast to the southwest which was the opposite direction in comparison to biomass burning (Factor F4). The fourth factor (C4) was recognised as soil with tramline construction and contributed $30 \%$ to $\mathrm{PM}_{\text {coarse. }}$ The diurnal pattern of this factor and the CPF showed similarities to the tramline construction factor in $\mathrm{PM}_{2.5}$. The presence of $\mathrm{K}(29.9 \%)$ and $\mathrm{Cl}(77 \%)$ species in abundance displayed that the fifth factor (C5) could be connected to biomass burning, with concentrations peaking at nights. This source appeared to be located in the same position where the agricultural area lies, supporting the idea that this factor was from mixed sources of agricultural fertilizer and biomass burning. Its contribution was $11 \%$ during the campaigns.

\section{Summary}

In this work, the elemental composition of fine and coarse atmospheric aerosol particles was determined with 2-h time resolution during severe smog episodes in November, 2011, in Debrecen, Hungary. Mass size distribution was also investigated at the same time to facilitate the identification of contributing sources. The mean concentrations of $\mathrm{S}, \mathrm{K}$ and $\mathrm{BC}$ were 2-3 times higher in the fine fraction than previously reported for the same location, which highlights the effect of smog events on PM composition. The enrichment factor was high for biomass burning, traffic, waste incineration and coal combustion-related elements $(\mathrm{S}, \mathrm{K}, \mathrm{Cl}, \mathrm{Cu}, \mathrm{Zn}, \mathrm{Pb})$, which primarily appeared in the droplet $(0.5-1 \mu \mathrm{m})$ mode.

PMF receptor model was applied to resolve and evaluate the contribution and composition of sources in both size fractions. The dominant sources in the $\mathrm{PM}_{2.5}$ fraction during these smog events in Debrecen, Hungary, were biomass burning and traffic, with a combined contribution of $70 \%$. In the coarse fraction, combustion sources were also present, although the dominant factors were soil $(32 \%)$ and tramline construction $(30 \%)$.

By coupling hourly source contributions with $\mathrm{CPF}$, the local $\mathrm{PM}_{2.5}$ and $\mathrm{PM}_{\text {coarse }}$ sources were explored. The main sources are derived from the following areas: biomass burning as domestic heating from suburban areas, traffic through direct emission from the city centre, and secondary sulphate from an industrial area.

To investigate the effects of a high-pressure blocking conditions on the city, PBL calculations were conducted. The highest accumulated pollution was observed under the lowest PBL height on 17 November. Waste incineration and biomass burning contributed the most to fine aerosol mass while traffic, soil, coal combustion and $\mathrm{Cl}$ to coarse aerosol mass. Thus, the feedback effect between the development of PBL and increased air pollution concentrations was apparent. Nevertheless, the diurnal pattern of the sources is strongly related to the routine activities in the city.

To the best of our knowledge, this is the first study that used high time resolution elemental composition and size distribution data combined with the analysis of meteorological conditions during smog episodes in Hungary, leading to a better identification of the possible causes, and thus contributing to the overall understanding of air pollution in the urban environment.

Supplementary Information The online version contains supplementary material available at https://doi.org/10.1007/s11869-021-01008-8.

Funding Open access funding provided by ELKH Institute for Nuclear Research. This work was supported by the National Research, Development and Innovation Office - NKFIH, contract number PD 125086, GINOP-2.3.2-15-2016-00055 Project through the National Research, Development and Innovation Office, Hungary, and by the European Union and the State of Hungary, co-financed by the European Regional Development Fund in the project of GINOP-2.3.215-2016-00009' ICER'.

\section{Declarations}

Disclaimer Reference to any companies or specific commercial products does not constitute.

Open Access This article is licensed under a Creative Commons Attribution 4.0 International License, which permits use, sharing, adaptation, distribution and reproduction in any medium or format, as long as you give appropriate credit to the original author(s) and the source, provide a link to the Creative Commons licence, and indicate if changes were made. The images or other third party material in this article are included in the article's Creative Commons licence, unless indicated otherwise in a credit line to the material. If material is not included in the article's Creative Commons licence and your intended use is not permitted by statutory regulation or exceeds the permitted use, you will need to obtain permission directly from the copyright holder. To view a copy of this licence, visit http://creativecommons.org/licenses/by/4.0/. 


\section{References}

Abbasi S, Jansson A, Olander L, Olofsson U, Larsson C, Sellgren U (2012) A field test study of airborne wear particles from a running regional train. Int J Rail Rapid Transit 226(1):95-109. https://doi. org/10.1177/0954409711408774

Adams HS, Nieuwenhuijsen MJ, Colvile RN, Older MJ, Kendall M (2002) Assessment of road users' elemental carbon personal exposure levels, London, UK. Atmos Environ 36:5335-5342. https://doi. org/10.1016/S1352-2310(02)00637-4

Almeida SM, Manousakas M, Diapouli E, Kertesz Z, Samek I, Hristova E, Sega K, Alvarez RP, Belis CA, Eleftheriadis K (2020) Ambient particulate matter source apportionment using receptor modelling in European and Central Asian urban areas. Environ Pollut 266: 115199. https://doi.org/10.1016/j.envpol.2020.115199

Amato F, Lucarelli F, Nava S, Calzolai G, Karanasiou A, Colombi C, Gianelle VL, Alves C, Custódio D, Eleftheriadis K, Diapouli E, Reche C, Alastuey A, Minguillón MC, Severi M, Becagli S, Nunes T, Cerqueira M, Pio C, Manousakas M, Maggos T, Vratolis S, Harrison RM, Querol X (2016) Case studies of source apportionment and suggested measures at Southern European Cities. Iss in Environ Scienc and Tech. https://doi.org/10.1039/97817826589-00168

Angyal A, Kertész Z, Szikszai Z, Szoboszlai Z (2010) Study of Clcontaining urban aerosol particles by ion beam analytical methods. Nucl Instrum and Methods in Phys Res Sect B 268:2211-2215. https://doi.org/10.1016/j.nimb.2010.02.090

Annegarn HJ, Flanz M, Kenntner T, Kneen MA, Helas G, Piketh SJ (1996) Airborne streaker sampling for PIXE analysis. Nucl Instrum and Methods in Phys Res Sect B 109-110:548-550. https://doi.org/10.1016/0168-583X(95)00966-3

Banerjee T, Murari V, Kumar M, Raju MP (2015) Source apportionment of airborne particulates through receptor modeling: Indian scenario. Atmos Res 164-165:167-187. https://doi.org/10.1016/j.atmosres.2015.04.017

Belis CA, Karagulian F, Larsen BR, Hopke PK (2013) Critical review and meta-analysis of ambient particulate matter source apportionment using receptor models in Europe. Atmos Environ 69:94-108. https://doi.org/10.1016/j.atmosenv.2012.11.009

Belis CA, Pikridas M, Lucarelli F, Petralia E, Cavalli F, Calzolai G, Berico M, Sciare J (2019) Source apportionment of fine PM by combining high time resolution organic and inorganic chemical composition datasets. Atmos Environ X 3:100046. https://doi.org/ 10.1016/j.aeaoa.2019.100046

Borbély-Kiss I, Koltay E, László S, Gy S, Zolnai L (1985) Experimental and theoretical calibration of a PIXE setup for K and L X-rays. Nucl Instrum and Methods in Phys Res Sect B 12:496-504. https://doi. org/10.1016/0168-583X(85)90506-3

Bougeault P, Lacarrére P (1989) Parameterization of orography-induced turbulence in amesobeta-scale model. Mon Weather Rev 117:18721890. https://doi.org/10.1175/1520-0493(1989)117<1872: POOITI $>2.0 . \mathrm{CO} ; 2$

Brown SG, Eberly S, Paatero P, Norris GA (2015) Methods for estimating uncertainty in PMF solutions: examples with ambient air and water quality data and guidance on reporting PMF reports. Sci Total Environ 518-519:626-635. https://doi.org/10.1016/j.scitotenv. 2015.01.022

Carslaw DC, Ropkins K (2012) Openair-an R package for airquality data analysis. Environ Model Softw 27-28:52-61. https://doi.org/ 10.1016/j.envsoft.2011.09.008

Chang CT, Tsai C (2003) A model of the relative humidity effect on the readings of beta-gauge monitor. Aerosol Sci 34:1685-1697. https:// doi.org/10.1016/S0021-8502(03)00356-2

Cséki G (2010) Formation of inversions in the Carpathian-Basin. Diploma work, Eötvös Loránd University, Budapest. (In Hungarian)

Diapouli E, Manousakas MI, Vratolis S, Vasilatou V, Pateraki S, Bairachtari KA, Querol X, Amato F, Alastuey A, Karanasiou AA,
Lucarelli F, Nava S, Calzolai G, Gianelle VL, Colombi C, Alves C, Custódio D, Pio C, Spyrou C, Kallos GB, Eleftheriadis K (2016) AIRUSE-LIFE +: Estimation of natural source contributions to urban ambient air PM10 and PM2.5 concentrations in Southern Europe. Implications to compliance with limit values. Atmos Chem Phys Discuss 1-25. https://doi.org/10.5194/acp-2016-781

EEA (1998) Urban Air Quality in Europe -Environmental monograph No $5 / 1998$.

EEA (2018) Air quality in Europe, 12/2018<https://wwweeaeuropaeu/ publications/air-quality-in-europe-2018> Accessed 9 July 2018

European Commission (2008) Directive 2008/50 of the European Parliament and of the Council of 21 May 2008 on Ambient Air Quality and Clean Air for Europe, Off J Eu. Com. Technical Report 2008/50/EC, L152

Ferenczi Z (2013) Predictability analysis of the PM2.5 and PM10 concentration in Budapest. Időjárás 117:359-375

Furu E, Katona-Szabo I, Angyal A, Szoboszlai Z, Török Z, Kertész Z (2015) The effect of the tramway track construction on the aerosol pollution in Debrecen, Hungary. Nucl Instrum and Methods in Phys Res Sect B 365:124-130. https://doi.org/10.1016/j.nimb.2015.08. 014

GOHBCH (2020) Air Quality Plan for the Reduction of Air Pollution in the Debrecen Region Zone Group 2014-2020, Environment Protection and Nature Conservation Department, Government Office for Hajdú-Bihar County, Hungary https://wwwkormanyhu/ download/7/92/e0000/Debrecen2pdf (in Hungarian) Accessed 4 April 2020

HAQN Hungarian Air Quality Network (n.d.) (http://www. levegominoseg.hu/)

Hovorka J, Pokorná P, Hopke PK, Krumal K, Mikuska P, Pisová M (2015) Wood combustion, a dominant source of winter aerosol in residential district in proximity to a large auromobile factory in Central Europe. Atmos Environ 113:98-107. https://doi.org/10. 1016/j.atmosenv.2015.04.068

Jason DS, Lindsay WS, Thomas JL, Douglas OJ, Barbara JB, James SB, Mary R (2011) Particulate matter induced health effects: who is susceptible? Environ Health Perspect 119:446-454. https://doi.org/ 10.1289/ehp. 1002255

Jöller M, Brunner T, Obernberger I (2007) Modeling of aerosol formation during biomass combustion for various furnace and boiler types. Fuel Process Technol 88:1136-1147. https://doi.org/10.1016/j. fuproc.2007.06.013

Kertész ZS, Szoboszlai Z, Angyal A, Dobos E, Borbély-Kiss I (2010) Identification and characterization of fine and coarse particulate matter sources in a middle European urban environment. Nucl Instrum and Methods in Phys Res Sect B 268:1924-1928. https://doi.org/10. 1016/j.nimb.2010.02.103

Kim E, Hopke PK, Edgerton ES (2003) Source identification of Atlanta aerosol by positive matrix factorization. J Air Waste Manage Assoc 53:731-739. https://doi.org/10.1080/10473289.2003.10466209

Leonia C, Pokorná P, Hovorka J, Masiol M, Topinka J, Zhao Y, Kurumal K, Cliff S, Mikuska P, Hopke PK (2018) Source apportionment of aerosol particles at a European air pollution hot spot using particle number size distributions and chemical composition. Environ Pollut 234:145-154. https://doi.org/10.1016/j.envpol.2017.10.097

Maenhaut W, Hillamo R, Mäkelä T, Jaffrezo JL, Bergin MH, Davidson CI (1996) Nucl Instrum and Methods in Phys Res Sect B 109-110: 482-487. https://doi.org/10.1016/0168-583X(95)00955-8

Manousakas M, Diapouli E, Belis CA, Vasilatou V, Gini M, Lucarelli F, Querol X, Eleftheriadis K (2021) Quantitative assessment of the variability in chemical profiles from source apportionment analysis of PM10 and PM2.5 at different sites within a large Metropolitan area. Environ Res 192:110257. https://doi.org/10.1016/j.envres. 2020.110257

Martins V, Moreno T, Minguillón MC, van Drooge BL, Reche C, Amato F, de Miguel E, Capdevila M, Centelles S, Querol X (2015) Origin 
of inorganic and organic components of PM2.5 in subway stations of Barcelona, Spain. Environ Pollut 208:125-136. https://doi.org/ 10.1016/j.envpol.2015.07.004

Martins V, Correia C, Cunha-Lopes I, Faria T, Diapouli E, Manousakas MI, Eleftheriadis K, Almeida SM (2021) Chemical characterisation of particulate matter in urban transport modes. J Environ Sci (China) 100:51-61. https://doi.org/10.1016/j.jes.2020.07.008

Mason B, Moore CB (1982) Principles of Geochemistry, 4th edn. Wiley, New York

MDVM (2011) Ministerial Decree 4/2011 (I. 14.) VM on air pollution thresholds and emissions ceilings for located air pollutant point sources http://njt.hu/cgi_bin/njt_doc.cgi?docid=137083.345067 (in Hungarian)

Minguillón MC, Querol X, Baltensperger U, Prévôt ASH (2012) Fine and coarse PM composition and sources in rural and urban Switzerland: local or regional pollution? Sci Total Environ 427-428:191-202. https://doi.org/10.1016/j.scitotenv.2012.04.030

Mira-Salama D, Grüning C, Jensen NR, Cavalli P, Putaud JP, Larsen BR, Raes F, Coe H (2008) Source attribution of urban smog episodes caused by coal combustion. Atmos Res 88:294-304. https://doi.org/ 10.1016/j.atmosres.2007.11.025

Moffet RC, Desyaterik Y, Hopkins RJ, Tivanki AV, Gilles MK, Wang Y, Shutthanandan V, Molina LT, Abraham RG, Johnsin KS, Mugica V, Molina MJ, Laskin A, Prather KA (2008) Characterization of aerosols containing $\mathrm{Zn}, \mathrm{Pb}$, and $\mathrm{Cl}$ from an industrial region of Mexico City. Environ Sci Technol 42:7091-7097. https://doi.org/ 10.1021/es7030483

Molnár A, Bécsi ZS, Imre K, Gácser V, Ferenczi Z (2016) Characterization of background aerosol properties during a wintertime smog episode. Aerosol Air Qual Res 16:1793-1804. https:// doi.org/10.4209/aaqr.2015.04.0205

Moreno T, Pérez N, Reche C, Martins V, de Miguel E, Capdevila M, Centelles S, Minguillón MC, Amato, Alastuey A, Querol X, Gibbons W (2014) Subway platform air quality: assessing the influences of tunnel ventilation, train piston effect and station design. Atmos Environ 2014;92:461-468. https://doi.org/10.1016/j. atmosenv.2014.04.043

Ogulei D, Hopke PK, Zhoua L, Pancras JP, Nairb N, Ondov JM (2006) Source apportionment of Baltimore aerosol from combined size distribution and chemical composition data. Atmos Environ 40:S396S410. https://doi.org/10.1016/j.atmosenv.2005.11.075

Paatero P (1997) Least squares formulation of robust non-negative factor analysis. Chemom Intell Lab Syst 37:23-35. https://doi.org/10. 1016/S0169-7439(96)00044-5

Paatero P, Tapper U (1994) Positive matrix factorization: a non-negative factor model optimal utilization of error estimates of data values. Environmentrics 5:111-126. https://doi.org/10.1002/env. 3170050203

Pant P, Harrison RM (2012) Critical review of receptor modelling for particulate matter: a case study of India. Atmos Environ 49:1-12. https://doi.org/10.1016/j.atmosenv.2011.11.060

Pateraki S, Manousakas M, Bairachtari K, Kantarelou V, Eleftheriadis K, Vasilakos C, Assimakopoulos VD, Maggos T (2019) The traffic signature on the vertical PM profile: environmental and health risks within an urban roadside environment. Sci Total Environ 646:448459. https://doi.org/10.1016/j.scitotenv.2018.07.289

Pernigotti D, Belis CA, Spanó L (2016) SPECIEUROPE: The European data base for PM source profiles. Atmos Pollut Res 7:307-314. https://doi.org/10.1016/j.apr.2015.10.007

Pokorna P, Hovorka J, Klán M, Hopke PK (2015) Source apportionment of size resolved particulate matter at a European air pollution hot spot. Sci Total Environ 502:172-183. https://doi.org/10.1016/j. scitotenv.2014.09.021

Pokorna P, Hovorka J, Hopke PK (2016) Elemental composition and source identification of very fine aerosol particles in a European air pollution hot-spot. Atmos Pollut Res 7:671-679. https://doi. org/10.1016/j.apr.2016.03.001

Polissar AV, Hopke PK, Poirot RL (2001) Atmospheric aerosol over Vermont: chemical composition and sources. Environ Sci Technol 35:4604-4621. https://doi.org/10.1021/es0105865

Pope CA, Dockery DW (2006) Health effects of fine particulate air pollution: lines that connect. J of the Air \& Waste Management Assoc 56:709-742. https://doi.org/10.1080/10473289.2006.10464485

Psanis C, Triantafyllou E, Giamarelou M, Manousakas M, Eleftheriadis K, Biskos G (2017) Particulate matter pollution from aviationrelated activity at a small airport of the Aegean Sea Insular Region. Sci Total Environ 596-597:187-193. https://doi.org/10. 1016/j.scitotenv.2017.04.078

Richard A, Gianini MFD, Mohr C, Furger M, Bukowiecki N, Minguillon MC, Lienemann P, Flechsig U, Appel K, DeCarlo PF, Heringa MF, Chirico R, Baltensperger U, Prevot ASH (2011) Source apportionment of size and time resolved trace elements and organic aerosols from an urban courtyard site in Switzerland. Atmos Chem Phys 17: 8945-8963. https://doi.org/10.5194/acp-11-8945-2011

Salma I, Maenhaut W, Zemplén-Papp É, Gy Z (2001) Comprehensive characterization of atmospheric aerosols in Budapest, Hungary: physicochemical properties of inorganic species. Atmos Environ 35:4367-4378. https://doi.org/10.1016/S1352-2310(01)00204-7

Santoso M, Lestiani DD, Mukhtar R, Hamonangan E, Syafrul H, Markwitz A, Hopke PK (2011) Preliminary study of the sources of ambient air pollution in Serpong, Indonesia. Atmos Pollut Res 2: 190-196. https://doi.org/10.5094/APR.2011.024

Seinfeld JH, Pandis SN (1998) Atmospheric chemistry and physics: from air pollution to climate change. Wiley-Interscience Publications, New York

Sharma SK, Mandal TK, Saxena M, Rohtash R, Sharma A, Gautam R (2014a) Source apportionment of PM10 by using positive matrix factorization at an urban site of Delhi, India. Urban Clim 10:656670. https://doi.org/10.1016/j.uclim.2013.11.002

Sharma SK, Mandal TK, Saxena M, Rashmi Sharma A, Datta A, Saud T (2014b) Variation of OC, EC, WSIC and trace metals of PM10 in Delhi, India. J Atmos Solar-Terrestrial Phys 113:10-22. https://doi. org/10.1016/j.jastp.2014.02.008

Sharma SK, Sharma A, Saxena M, Choudhary N, Masiwal R, Mandal TK, Sharma C (2016) Chemical characterization and source apportionment of aerosol at an urban area of Central Delhi, India. Atmos Pollut Res 7:110-121. https://doi.org/10.1016/j.apr.2015.08.002

Shin S, Jung C, Kim Y (2011) Analysis of the measurement difference for the PM10 Concentratios between Beta-ray absorption and gravimetric methods at Gosan. Aerosol Air Qual Res 11:846-853. https://doi. org/10.4209/aaqr.2011.04.0041

Swietlicki E, Puri ESS, Hansson HC, Edner H (1996) Urban air pollution source apportionment using a combination of aerosol and gas monitoring techniques. Atmos Environ 30:2795-2809. https://doi.org/ 10.1016/1352-2310(95)00322-3

Szabó G (2009) PIXEKLM Program User Guide. ATOMKI, Debrecen

Szabó G, Borbély-Kiss I (1993) PIXYKLM computer package for PIXE analyses. Nucl Instrum and Methods in Phys Res Sect B 75:123127. https://doi.org/10.1016/0168-583X(93)95626-G

Szintai B, Kaufmann P (2008) TKE as a measure of turbulence. COSMO Newsletter 8:2-9

Takahashi K, Minoura H, Sakamoto K (2008) Examination of discrepancies between beta attenuation and gravimetric methods for the monitoring of particulate matter. Atmos Environ 42:5232-5240. https://doi.org/10.1016/j.atmosenv.2008.02.057

Vecchi R, Chiari M, D'Alessandro A, Fermo P, Lucarelli F, Mayyei F, Nava S, Piayyalunga A, Prati P, Silvani F, Valli G (2008) A mass closure and PMF source apportionment study on the submicron aerosol fraction at urban sites in Italy. Atmos Environ 42:2240 2253. https://doi.org/10.1016/j.atmosenv.2007.11.039 
Viana M, Kuhlbusch TAJ, Querol X, Alastuey A, Harrison RM, Hopke PK, Winiwarter W, Vallius M, Szidat S, Prevot ASH, Hueglin C, Bloemen H, Wahlin P, Vecchi R, Miranda AI, Kasper-Giebl A, Maenhaut W, Hitzenberger R (2008) Source apportionment of particulate matter in Europe: a review of methods and results. Aerosol Sci 39:827-849. https://doi.org/10.1016/j.jaerosci.2008.05.007
Wiesen (2017) Air pollution emergency schemes (Smog Alerts) in Europe https://www.levego.hu/sites/default/files/smog emergency_schemes_in_europe_201703.pdf. Accessed Marc 2017

Publisher's note Springer Nature remains neutral with regard to jurisdictional claims in published maps and institutional affiliations. 